\title{
Clear cell myeloma. Report of two cases with comments on morphogenesis and ubiquitin expression
}

\author{
Alexandr Švec $\cdot$ Zuzana Velenská • Radek Jakša • \\ Evženie Kolešková • Ctibor Povýšil
}

Received: 9 October 2010 /Accepted: 3 November 2010/Published online: 17 November 2010

(C) Springer-Verlag 2010

\begin{abstract}
Three bone marrow trephine biopsies from two multiple myeloma patients were involved by a diffuse infiltrate of microvacuolated plasma cells with a variable number of signet ring cells, CD138, k-light chains, and ubiquitin positive. The vacuoles remained clear on PAS and in May-Grünwald-Giemsa-stained bone marrow aspirates. Differential diagnosis on conventional stains included malignant epithelial and mesenchymal tumors, nonneoplastic histiocytes, and fixation artifacts. Electron microscopy revealed translucent vacuoles with no apparent membrane and a fuzzy internal surface occasionally merging with smaller membrane-delineated spaces filled with granular material, without communication with cisternae of rough endoplasmic reticulum. Rare multivesicular bodies with dilated intralumenal vesicles were noted. The findings concur with the presumed derivation of the vacuoles from the endolysosomal compartment. Strong ubiquitin expression was encountered in neoplastic plasma cells but not in non-neoplastic plasma cells, presumably due to the endoplasmic reticulum-associated degradation, triggered by excessive production of misfolded immunoglobulins in the former.
\end{abstract}

\footnotetext{
A. Švec $(\bowtie) \cdot Z$. Velenská $\cdot$ R. Jakša $\cdot$ C. Povýšil

Department of Pathology, General Teaching Hospital and

First School of Medicine, Charles University,

Studničkova 2,

128 00, Prague 2, Czech Republic

e-mail: alexandr.svec@stees.nhs.uk

E. Kolešková

First Clinic of Internal Medicine, General Teaching Hospital and First School of Medicine, Charles University,

Unemocnice 4,

128 00, Prague 2, Czech Republic
}

Keywords Bone marrow - Clear cell myeloma · PseudoGaucher cells $\cdot$ Signet ring cells $\cdot$ Ubiquitin

\section{Introduction}

A diagnosis of plasma cell myeloma is established by integration of clinical, radiographic, and biochemical findings and confirmed by bone marrow trephine biopsy and/or aspirate [1]. Sheets or a diffuse infiltrate of neoplastic plasma cells is recognized with confidence on hematoxylin and eosin (H\&E) or Giemsa-stained sections in most of the cases. However, cytological variants imitating other neoplasms, such as metastatic carcinoma, lymphoma, myeloid or monocytic leukemia, sarcoma or non-neoplastic lesions, such as storage diseases or inflammatory conditions, can cause a diagnostic dilemma [2]. A neoplastic plasma cell infiltrate obscured by abundant pseudo-Gaucher cells has been recently reported as a diagnostic pitfall [3]. Herein, we are reporting on two cases of clear cell myeloma (CCM) masquerading as a histiocytic infiltrate and a metastatic signet ring cell carcinoma. We also comment on morphogenesis of the vacuolar change and expression of ubiquitin in myeloma cells.

\section{Case 1}

A 58-year-old male presented with a compressive fracture of the thoracic spine in June 2005 followed by progressive fatigue. Clinical investigations revealed evidence of plasma cell myeloma with plasmablastic leukemia, clinical stage IIIB (serum M-protein IgA $\kappa(42.76 \mathrm{~g} / \mathrm{l})$, Bence-Jones protein $\mathrm{K}(1.99 \mathrm{~g} / \mathrm{l}), 80 \%$ of plasma cells in bone marrow aspirate analyzed by FACS and cytogenetics (CD138+, 
CD38+, CD56+, CD45-, del17p, and monosomy13), 20\% of plasma cells in the peripheral blood and multiple osteolytic lesions in the axial skeleton and upper extremities). Treatment with 4 cycles of VAD (vincristine, doxorubicine, dexamethasone), autologous stem cell transplantation, Thalidomide and Velcade achieved only a transient episode of partial remission. The patient died 36 months after the diagnosis.

\section{Case 2}

A 59-year-old male underwent medical examination in 2008 for a 3-month history of back pain. This revealed evidence of multiple myeloma clinical stage IIIA (serum M-protein IgG $\mathrm{K}(60,5 \mathrm{~g} / \mathrm{l})$, Bence-Jones protein $(0,671 \mathrm{~g} / 1), 74 \%$ plasma cell population (CD138+, CD38+, CD56+, CD45-) on FACS analysis of bone marrow aspirate and multiple osteolytic lesions in the axial skeleton, lower and upper extremities.

Treatment with 4 cycles of Velcade, thalidomide and dexamethason) and autologous stem cell transplantation induced complete remission (FW 7, Hb 143g/l, serum protein $74 \mathrm{~g} / \mathrm{l}$, no paraproteinemia or proteinuria). The patient is alive and well 24 months after the diagnosis.

\section{Material and methods}

Both cases were identified in the course of routine diagnostic work. Two sequential trephine biopsies and bone marrow aspirates were available from Case 1 and one biopsy and aspirate from Case 2.

Bone marrow trephines were fixed and decalcified in formic acid-formalin solution for $24 \mathrm{~h}$. Upon routine processing, the paraffin-embedded trephines were stained with H\&E, PAS, Giemsa, reticulin and Sudan (Case 2) stains. An antigen retrieval step by heating in citrate buffer $\mathrm{pH} 6.0$ at $98^{\circ} \mathrm{C}$ for 40 min preceded application of primary antibodies (clone, dilution, source): CD138 (M115, 1:50, DAKO), K-light chains (polyclonal, 1:50 000, DAKO), $\lambda$-light chains (polyclonal, 1:50 000, DAKO), CD45 (2B11+ PD7/26, 1:100, DAKO),CD68 (PGM1, 1:100, DAKO), pancytokeratins (AE1/3,1:50, DAKO), and ubiquitin (polyclonal, 1:1500, DAKO). The reaction products were detected by Histofine (Nichirei Biosciences, Japan) and diaminobenzidine as chromogen.

Samples for electron microscopy were extracted from the paraffin-embedded tissue, deparaffinized and postfixed overnight in $1 \%$ osmium tetroxide and embedded in epoxy resin. Ultra thin sections were double stained with uranylacetatelead citrate. The bone marrow aspirates were air dried and stained with May-Grünwald-Giemsa.

\section{Results}

Histopathological and immunohistochemical findings

The initial bone marrow trephine biopsy of Case 1 (Fig. 1a) and the bone marrow trephine of Case 2 (Fig. 1e) showed similar histological findings dominated by high cellularity but faint appearances on low-power magnification. On high-power magnification, diffuse infiltration by uniform population of medium-sized foam cells (FC), possessing eccentric round nuclei with dense homogenous or finely granular chromatin and no or inconspicuous nucleoli was observed. Signet ring cells (SRC) with compressed nuclei by a single water-clear vacuole were occasionally noted, as well as occasional mature plasma cells, forming a single ill-defined aggregate in Case 2 (Fig. 2). Hematopoiesis was reduced to individual hematopoietic cells, or their clusters scattered in the neoplastic background in Case 1, and to a sharply demarcated area with myelodysplastic features in Case 2.

The follow-up bone marrow trephine biopsy of Case 1 (Fig. 1c) showed a persistent neoplastic infiltrate with a marked shift towards large SRC at the expense of FC. Immunohistochemical studies in all three biopsies demonstrated expression of CD138, K-light chain (Fig. 2), and ubiquitin (Fig. 3), whereas $\lambda$-light chain (Fig. 2 inset), CD68 (PGM1), and pancytokeratins (AE1/3) yielded negative results. The ubiquitin and $k$-light chain reaction products gave the FC speckled appearances and created a fuzzy line along the inner surface of SRC, leaving the vacuoles water clear. Notably, four cases of bone marrow plasma cell myeloma and one solitary bone plasmacytoma gave a strong ubiquitin reaction, whereas plasma cells in two inflammatory infiltrates and one case of rheumatoid lymphadenitis were weakly positive or negative.

The vacuoles remained unstained on PAS, Sudan, and May-Grünwald-Giemsa (bone marrow aspirates). Although FC were predominantly microvacuolated, a spectrum of vacuoles of larger size was apparent, suggesting evolution into the final stage of SRC. Moreover, ordering of all three biopsies and aspirates by the number of SRC revealed a morphological continuum from predominantly FC differentiation, imitating accumulation of histiocytes 1(Fig. 1a, b, e, f), to predominantly SRC differentiation, imitating SRC carcinoma (Fig. 1c, d).

\section{Electron microscopic findings}

The follow-up bone marrow trephine biopsy of Case 1 and Case 2 were studied. Neoplastic plasma cells were identified by nuclei with clumped chromatin, often possessing a small nucleolus, and/or an abundant rough endoplasmic reticulum (RER). The SRC cells contained a 

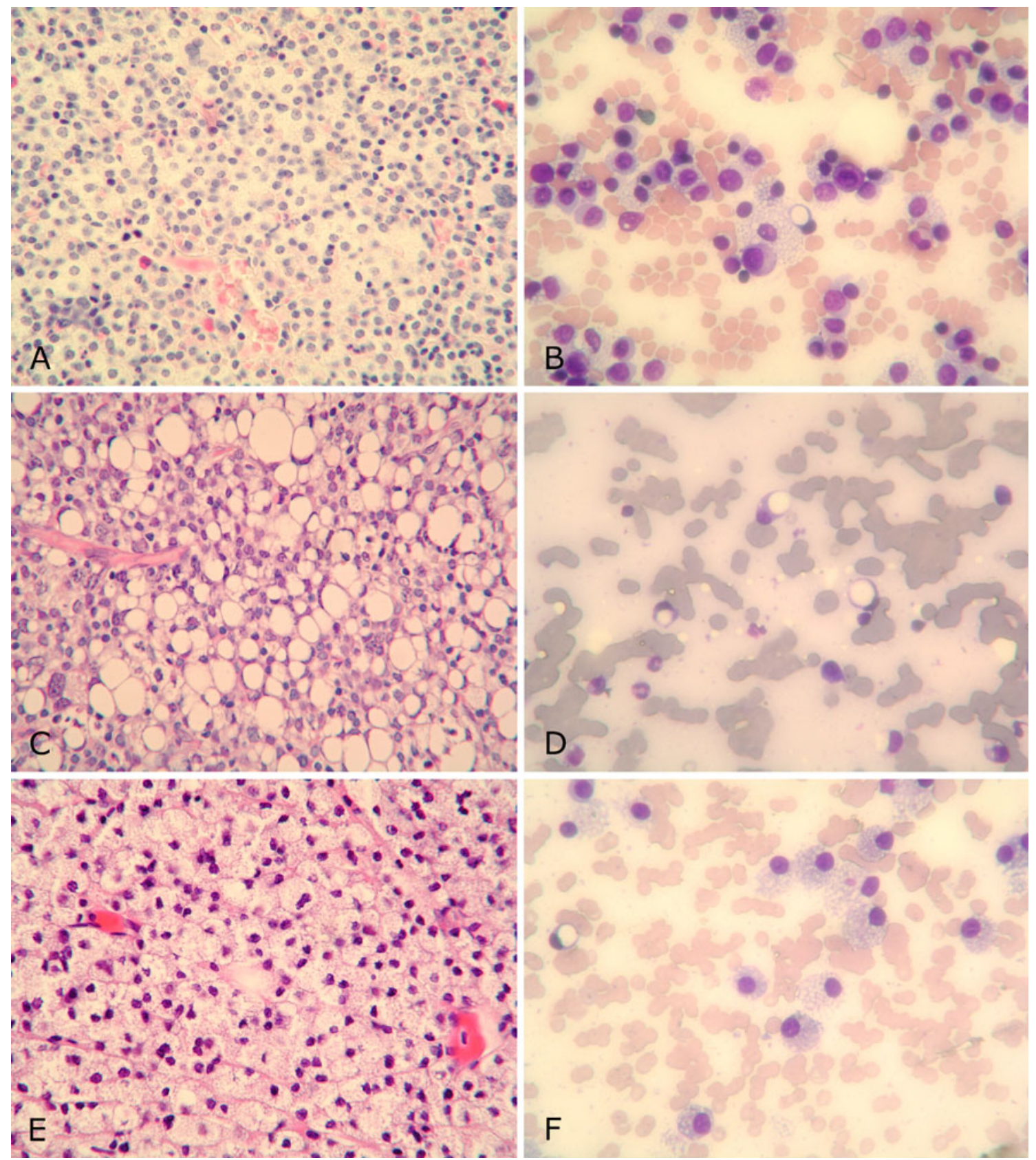

Fig. 1 a, b. Case 1-initial biopsy. c, d. Case 1-follow-up biopsy. e, f. Case 2. Bone marrow trephine biopsies (a, c, e) and bone marrow aspirates $(b, d, f)$ showing numerous vacuolated neoplastic plasma

cells. These imitate histiocytes in $\mathrm{a}, \mathrm{b}$ and $\mathrm{e}, \mathrm{f}$ and signet ring cell adenocarcinoma in c, d. h, e. May-Grünwald-Giemsa. Magnification $\times 600$

single translucent vacuole compressing a sickle-shaped nucleus, while FC possessed centrally placed nuclei. Their cytoplasm was fenestrated by multiple translucent vacuoles, some delineated by incomplete, poorly preserved membranes, with residues of fluffy granular material in places. The vacuoles occasionally merged with small membranedelineated spaces filled with granular material of moderate density (Fig. 4, asterisk). A multivesicular body with dilated intralumenal vesicles was noted (Fig. 5). RER

formed distinct narrow cisternae without any evidence of communication with the vacuoles (Fig. 4, arrow).

\section{Discussion}

Chen et al. were the first to introduce a descriptive term CCM for a myeloma characterized by FC and SRC differentiation in 1985[4] having been reportedly preceded 


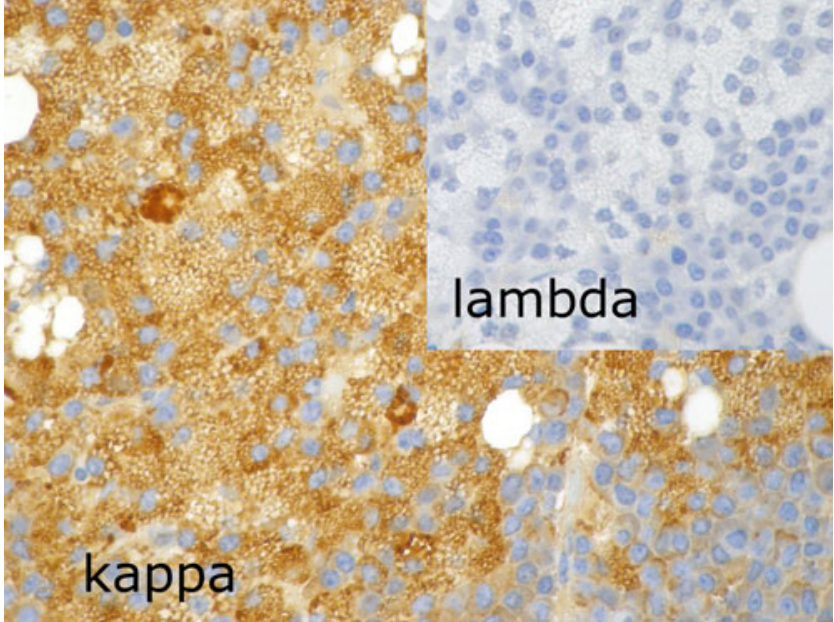

Fig. 2 Case 2. Immunohistochemical detection of light chains, $k$ positive and $\lambda$ negative (inset). Unstained microvacuoles give the cells speckled appearances. A cluster of well-differentiated neoplastic plasma cells is shown in the right-lower quadrant. Magnification $\times 600$

only by an abstract publication 'Signet ring cell myeloma' presented by Jacot-des-Combes and Kapacini in 1984 [5].

Searching the PubMed database, we identified only six myeloma cases $[4,6-10]$ and one monoclonal gammopathy of uncertain significance [11] displaying a vacuolar change. This was in stark contrast to over 100 reported cases of SRC malignant lymphomas. The clinicopathologic data, including the presented two cases, are summarized in Table 1. Briefly, all nine patients were males aged from 44 to 73 years at presentation (mean 62, median 61). Monoclonal IgG:IgA ratio was 4:3 (seven cases compared), and paraprotein $\kappa: \lambda$ ratio was $7: 2$. The values are skewed towards male predominance and a high proportion of $\operatorname{IgA}$,

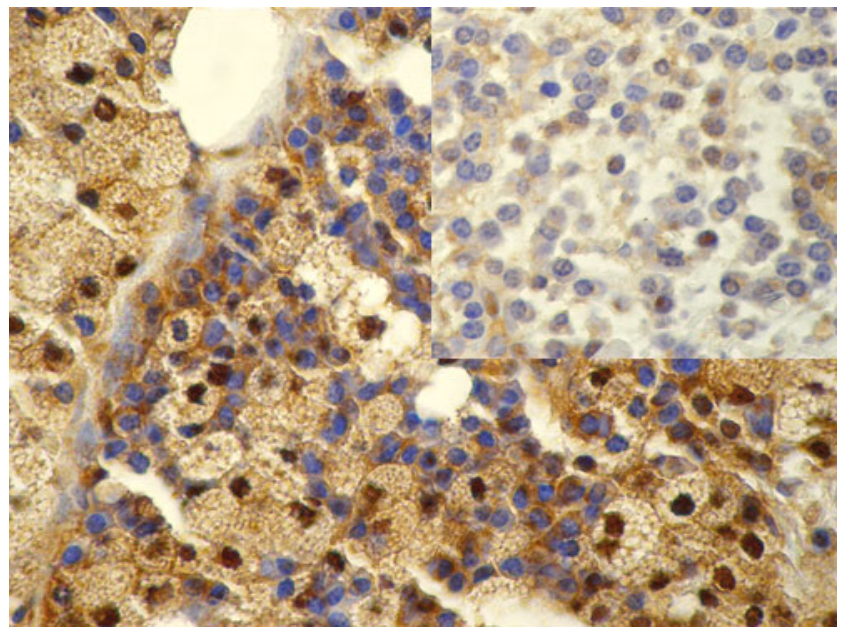

Fig. 3 Case 2.Immunohistochemical detection of ubiquitin, giving a strong reaction similar to $\mathrm{K}$-light chains in neoplastic plasma cells and a weak-to-no reaction in plasma cells of chronic inflammatory infiltrate (inset). Magnification $\times 600$

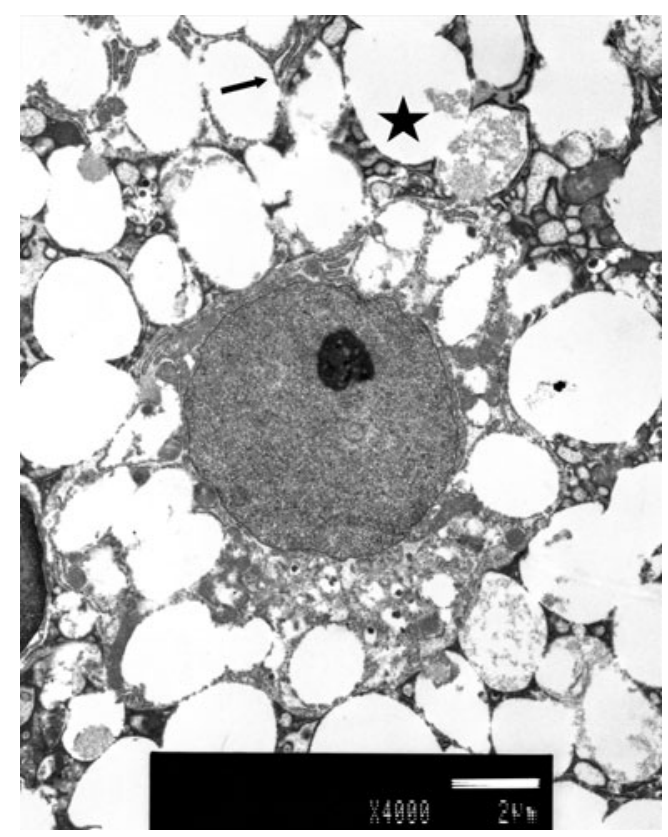

Fig. 4 Case 1. Follow-up biopsy. Electronogram showing an immature plasma cell with translucent membrane-free large vacuoles and occasional small membrane-bound spaces with granular, moderately dense contents, rarely merging with the large vacuoles (asterisk). RER is compressed between the vacuoles (arrow). Bar $2 \mu \mathrm{m}$ Uranyl acetate. Magnification $\times 4000$

but the significance is unclear due to the small number of cases.

Despite its rarity, awareness of FC and SRC differentiation in multiple myeloma is important in individual

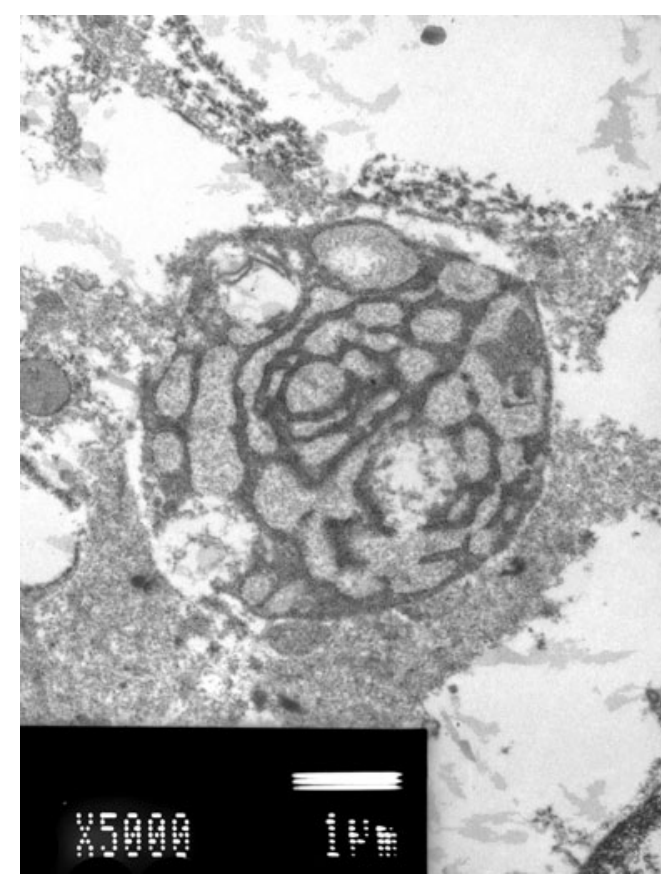

Fig. 5 Case 1. A multivesicular body with dilated intralumenal vesicles and a margin of a large vacuole with a fuzzy internal surface. Bar $1 \mu \mathrm{m}$. Uranyl acetate. Magnification $\times 5000$ 
Table 1 Clinicopathologic data

\begin{tabular}{|c|c|c|c|c|c|c|c|c|}
\hline $\begin{array}{l}\text { Year of } \\
\text { publication } \\
\text { Reference }\end{array}$ & Age & Sex & Diagnosis & $\begin{array}{l}\text { M-protein } \\
\text { paraprotein }\end{array}$ & Material & $\begin{array}{l}\text { Light microscopy } \\
\text { proportion of PLC } \\
\text { and vacuolated cells }\end{array}$ & $\begin{array}{l}\text { Electron } \\
\text { microscopy } \\
\text { membrane }\end{array}$ & AP \\
\hline $1985 / 4$ & 70 & M & clear cell myeloma & $\operatorname{IgA~} \mathrm{K}$ & $\begin{array}{l}\text { bone tumor } \\
\text { BM smear } \\
\text { BM trephine }\end{array}$ & $\begin{array}{l}40 \% \text { PLC, most } \\
\text { vacuolated }\end{array}$ & $\begin{array}{l}\text { Incomplete } \\
\text { occasional }\end{array}$ & nd \\
\hline 1986/9 & 61 & M & multiple myeloma & $\operatorname{IgG~} \mathrm{K}$ & BM smear & $\begin{array}{l}77 \% \text { MM cells, } \\
\text { practically all vac. }\end{array}$ & not done & pos \\
\hline $1989 / 10$ & 60 & M & multiple myeloma & $\begin{array}{l}\text { no spike } \\
\text { BJP K }\end{array}$ & BM smear & $\begin{array}{l}\text { marked proliferation } \\
\text { of PLC, most with } \\
\text { few vacuoles }\end{array}$ & $\begin{array}{l}\text { membrane } \\
\text { demarcated } \\
\text { vacuoles }\end{array}$ & \\
\hline 1990/7 & 44 & M & $\begin{array}{l}\text { multiple myeloma } \\
\text { with SRC }\end{array}$ & $\operatorname{IgG~} \mathrm{K}$ & BM trephine & $\begin{array}{l}\text { dense infiltrate of PLC, } \\
\text { many solitary or } \\
\text { multiple vacuoles }\end{array}$ & $\begin{array}{l}\text { limiting } \\
\text { membrane }\end{array}$ & nd \\
\hline 1992/8 & 67 & M & $\begin{array}{l}\text { multiple myeloma } \\
\text { PLC leukemia }\end{array}$ & $\operatorname{IgG} \lambda$ & $\begin{array}{l}\text { BM trephine } \\
\text { PB }\end{array}$ & $\begin{array}{l}\text { 90\% PLC, most vac. } \\
\text { vac.PLC in PB }\end{array}$ & $\begin{array}{l}\text { distinct } \\
\text { membrane }\end{array}$ & \\
\hline 1997/6 & 69 & M & BJM with SRC & not specified $\lambda$ & $\begin{array}{l}\text { BM smear } \\
\text { BM trephine }\end{array}$ & $\begin{array}{l}\text { several larger cells } \\
\text { with single vacuoles }\end{array}$ & not done & nd \\
\hline $1997 / 11$ & 73 & M & MGUS & $\operatorname{IgAK}$ & BM smear & some & not done & nd \\
\hline Case 1 & 58 & M & clear cell myeloma & $\operatorname{IgA~} \mathrm{K}$ & BM trephine & $\begin{array}{l}90-95 \% \text { MM cells, } \\
\text { practically all vac. }\end{array}$ & indistinct & nd \\
\hline Case 2 & 59 & M & clear cell myeloma & $\operatorname{IgG~} \mathrm{K}$ & BM trephine & $\begin{array}{l}80 \% \text { MM cells, } \\
\text { practically all vac. }\end{array}$ & indistinct & nd \\
\hline
\end{tabular}

Ref reference number, $P L C$ plasma cells, $B J P / M$ Bence-Jones protein/myeloma, SRC signet ring cells, $P B$ peripheral blood, vac vacuolated/ vacuoles, $A P$ acid phosphatase, $n d$ not done

cases, as the appearances both in bone marrow trephines and aspirates lead to a broad differential diagnosis, including metastatic SRC adenocarcinoma, liposarcoma, Langerhans cell histiocytosis, pseudo-Gaucher cells or fixation artifacts. Our observations suggest that nuclear appearances, scattered mature plasma cells, and transitional forms of FC to SRC are signs which should raise suspicion of CCM and prompt immunohistochemical investigations. Comparison of the herein presented figures to those shown in Ref. 3, documents striking morphological similarity between histiocytes and neoplastic FC of clear cell myeloma.

In 1990, Eyden et al. published an ultrastructural study providing evidence that vacuoles in SRC B- and T-cell lymphomas arise from multivesicular bodies (MVB) and suggested that their genesis is related to altered membrane recirculation [12]. MVB represent late endosomes lacking recirculation-related enzymes and carrying ubiquitinylated cargo, destined for degradation upon merging with lysosomes [13]. Indeed, acid phosphatase was identified in all three tested cases of vacuolated myeloma cells [8-10], and experimental manipulation of MVB induced a vacuolar change in cell culture [14]. Our findings of empty vacuoles on conventional stains and no-reaction products on immunohistochemical detection of light chains, no evidence of communication with RER, and a finding of MVB harboring dilated microvesicles on ultrastructural studies, lend further support to the origin of the vacuoles from the endolysosomal compartment.

Finally, we are not aware of any previous reports on differences in ubiquitin expression in neoplastic and nonneoplastic plasma cells detected by immunohistochemistry. Obviously, our observation is preliminary and needs verification in a robust study. However, it concurs with recent experimental data $[15,16]$ and biological theory, which offers a good explanation based on the unfolded protein response to massive production of misfolded immunoglobulins and/or their subunits in neoplastic, but not reactive plasma cells. This triggers the endoplasmic reticulum-associated degradation, which utilizes cytoplasmic ubiquitinylation for targeting the misfolded proteins for degradation in the proteasome [17]. We hypothesize that upregulation of ubiquitin synthesis in myeloma cells explains the observed differences.

In conclusion, CCM is a rare differentiation pattern of multiple myeloma, which should be included in the differential diagnosis of disorders dominated by the presence of histiocytes or SRC in bone marrow trephine biopsies and aspirates. SRC represent the final evolutionary step in the vacuolar change, which in one of the presented cases, correlated with clinical progression. The vacuoles originate in the endolysosomal compartment. 
Experimental and theoretical data, concurrent with the presented observation, suggest that ubiquitin could become an immunohistochemical adjunct in detection of neoplastic plasma cells.

Acknowledgments The authors are grateful to Mrs Blanka Veghova and Mrs Eva Kirchmanova for their excellent technical assistance and Mrs Denise Davison for editing the English language.

Conflict of interest The authors declare that they have no conflict of interest.

\section{References}

1. McKenna R, Kyle R, Kuehl WM et al (2008) Plasma cell neoplasms. In: Swerdlow SH, Campo E, Harris NL et al (eds) WHO classification of tumours of haematopoietic and lymphoid tissues, 4th edn. IARC, Lyon, pp 200-213

2. Banerjee SS, Verma S, Shanks JH (2004) Morphological variants of plasma cell tumours. Histopathology 44:2-8

3. Shenjere P, Roy A, Eyden B, Banerjee SS (2008) Pseudo-Gaucher cells in multiple myeloma. Int J Surg Pathol 16:176-179

4. Chen KT, Ma CK, Nelson JW, Padmanabhan A, Brittin GM (1985) Clear cell myeloma. Am J Surg Pathol 9:149-154

5. Eyden BP, Banerjee SS (1991) Multiple myeloma showing signetring cell change. Histopathology 18:577-578, In reply to: Dorfman $\mathrm{RF}$

6. Caenazzo A, Sartori D, Poletti A (1997) Bence Jones myeloma with signet-ring-like plasma cells. Haematologica 82:122
7. Eyden BP, Banerjee SS (1990) Multiple myeloma showing signetring cell change. Histopathology 17:170-172

8. Fujii H, Nakagawa H, Kanoh T, Matsuyama F, Urata Y (1992) Vacuolar inclusions with multivesicular structure in leukemic multiple myeloma. Rinsho Ketsueki 33:1090-1094

9. Kanoh T, Yasuda N, Takamatsu T, Uchino H (1986) Vacuolated plasma cells in multiple myeloma. Tohoku J Exp Med 148:361-364

10. Yasuda N, Kanoh T, Uchino H, Ogawa K (1989) Vacuolated plasma cell: ultrastructural distribution of acid phosphatase and intracellular immunoglobulin. Acta Haematol 81:203-207

11. Regazzoli A, Pozzi A, Rossi G (1997) Pseudo-Gaucher plasma cells in the bone marrow of a patient with monoclonal gammopathy of undetermined significance. Haematologica 82:727

12. Eyden BP, Cross PA, Harris M (1990) The ultrastructure of signetring cell non-Hodgkin's lymphoma. Virchows Arch A Pathol Anat Histopathol 417:395-404

13. Falguières T, Luyet PP, Gruenberg J (2009) Molecular assemblies and membrane domains in multivesicular endosome dynamics. Exp Cell Res 315:1567-1573

14. Razi M, Futter CE (2006) Distinct roles for Tsg101 and Hrs in multivesicular body formation and inward vesiculation. Mol Biol Cell 17:3469-3483

15. Edwards CM, Lwin ST, Fowler JA, Oyajobi BO, Zhuang J, Bates AL, Mundy GR (2009) Myeloma cells exhibit an increase in proteasome activity and an enhanced response to proteasome inhibition in the bone marrow microenvironment in vivo. Am J Hematol 84:268-272

16. Obeng EA, Carlson LM, Gutman DM, Harrington WJ, Lee KP, Boise LH (2006) Proteasome inhibitors induce a terminal unfolded protein response in multiple myeloma cells. Blood 107:4907-4916

17. Brewer JW, Hendershot LM (2005) Building an antibody factory: a job for the unfolded protein response. Nat Immunol 6:23-29 